\title{
ANALYSIS OF ENERGY CONSUMPTION OF CRUSHING PROCESSES - COMPARISON OF ONE-STAGE AND TWO-STAGE PROCESSES
}

\author{
PAWEŁ CiĘŻKOWSKI, JAN MACIEJEWSKI, SEBASTIAN BĄK \\ Warsaw University of Technology, Faculty of Automotive and Construction Machinery Engineering, \\ Institute of Construction Machinery, \\ e-mail: pawel.ciezkowski@simr.pw.edu.pl,jan.maciejewski@simr.pw.edu.pl,sebastian.bak@simr.pw.edu.pl
}

\begin{abstract}
This paper presents experimental comparison of two machine crushing technologies: one-stage and two-stage. The study was carried on a model double-toggle jaw crusher which allows crushing forces, energy and toggle displacement to be measured. The main aim of the work was to determine the energy consumption of crushing process assuming a given level of fragmentation. Studies were performed on three rocks: granite "Strzegom", limestone "Morawica" and sandstone "Mucharz". The material tested had a cubic shape and average dimension of $90 \mathrm{~mm}$. One-stage crushing was carried out for outlet slot $e_{r}=11 \mathrm{~mm}$, and two-stage crushing for $e_{r}=24 \mathrm{~mm}$ and $11 \mathrm{~mm}$. In the tests special design of variable profile moving jaw was used and fixed jaw was flat. The analysis of the results shows that taking into account energy consumption, it is better to use two-stage crushing process. For given materials energy consumption in the two-stage crushing process was reduced by $30 \%$.
\end{abstract}

Key words: rock crushing, jaw crusher, crushing efficiency, two stage crushing process

\section{INTRODUCTION}

The main aim of processing rock raw materials is to prepare and process the rocks to a condition that meets the commercial requirements for quality parameters as well as the production of suitable products in accordance with the requirements of the standards. Due to the significant development of road and rail infrastructure and to growing demand for high quality aggregates, methods of crushing should be sought which ensure high product quality and low cost of production.

Growing demand for aggregates of various fractions often leads to situations in which producers, companies selling aggregates, have to adapt fast to requirements of individual customers. In addition, the economics of production requires a comprehensive and optimal use of the raw material. Hence, it is becoming more and more common for the aggregate manufacturer to further refine its current product to meet the specific customer requirements. This involves the need to expand technological lines by using additional processing equipment, different from that operating in the main technological line.

In aggregate processing plants, jaw, cone and impact crushers are most commonly used. At the initial stages of crushing, jaw or cone crushers are usually used. The advantages of the jaw crusher are the low operating and maintenance costs and simple maintenance.

When reviewing literature it can be noticed that there are many devices for crushing of fragile materials. These machines are characterized by different capacities, construction, energy consumption and destination (Tromans [16], Foszcz and Gawenda [7], Ciężkowski [2],[3], Ciężkowski and Maciejewski [4], Ciężkowski et al. [5], Foszcz and Włodarczyk [9], Kobiałka and Naziemiec [12], Rumpf [14], Klushancev et al. [11]).

These devices are individually selected for specific technological processes. One thing is certain: the process of crushing entails high energy consumption (Tęsiorowski [15], Numbia et al. [19]), and wear off the crusher components (Mierzwa et al. [18]), which aggravates their efficiency. Strength parameters of the feed (Akbarnezhad et al. [1]) and physical characteristics such as moisture content (Fuerstenau and Abouzeid [10]) also avert influence on the process of crushing.

In the present study, the machine crushing process were performed on doubble-toggle jaw crusher, shown schematically in Fig. 1a. Fig. 1b presents the outlet slot $e_{r}$ measurement principle adopted in the experiment.

The most important operational and technical parameters of the jaw crushers are the dimension of the inlet slot $a \times b$, the displacement of the moving jaw $s$ (distance between the plates at the narrowest point of 
(a)

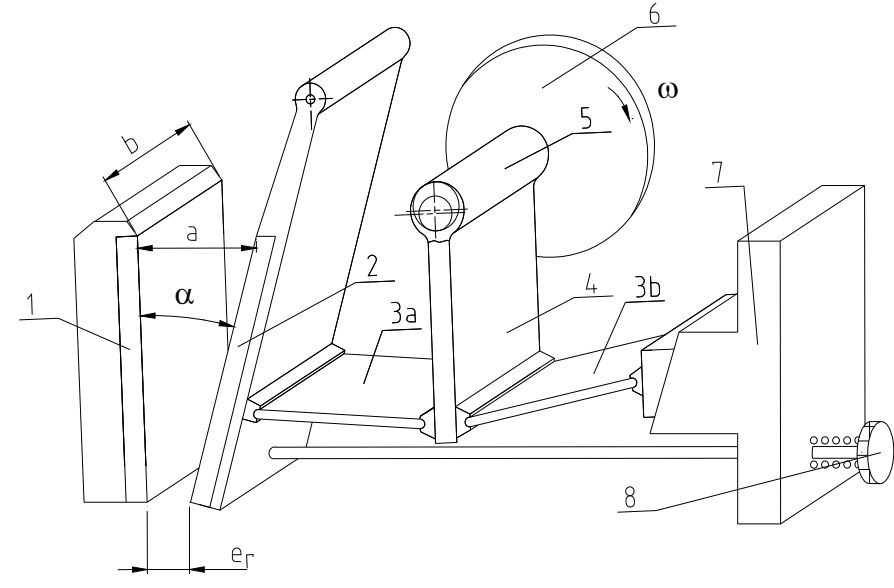

(b)

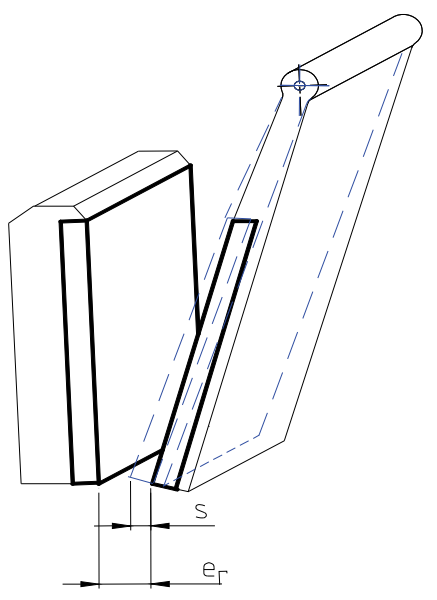

Fig. 1. (a) Schematic diagram of laboratory jaw crusher:

1 - fixed jaw, 2 - moving jaw, 3a, 3b-toggle plates, 4 - pitman, 5 - eccentric shaft, $\mathrm{a}, \mathrm{b}$ - width and length of the inlet slot, 6 - flywheel, 7 - rear wall, 8 - outlet slot $e_{r}$ adjusting device,

(b) methodology of outlet slot width measurement, s - moving jaw displacement, $e_{r}$ - outlet slot dimension

the working chamber), nip angle $\alpha$ (angle between the surfaces of the fixed and moving jaw in the reverse position, when the moving jaw is as close as possible to the fixed one), the angular velocity of the drive shaft $n$ (no-load running), the dimension of the outlet slot $e_{r}$, the cross and longitudinal profiles of crushing plates (Kobiałka and Naziemiec [12], Zawada and Pawlak [17]). Under industrial conditions, the outlet slot $e_{r}$ and the moving jaw displacement $s$ are regulated. Other parameters are selected at the design stage for a given process line (Gawenda [8]).

The present paper is a continuation of the work on optimization of the crushing process at the Institute of Construction Machinery Engineering (Ciężkowski et al. [5]). The purpose of the experiments carried out in this work is to compare the comminution of the feed in a two-stage and a single-stage crushing process and to determine technological parameters of the latter, i.e., performance, effective energy and crushing forces.

\section{EXPERIMENTAL METHODOLOGY}

The object of the study was a double-toggle jaw crusher (Ciężkowski (ed.) [6]). The test machine fully corresponds structurally and functionally to doubletoggle jaw crushers used for industrial purposes, dif-

Table 1. Strength parameters of the feed

\begin{tabular}{|l|c|c|c|}
\hline \multirow{2}{*}{\multicolumn{1}{|c|}{ Strength parameters }} & \multicolumn{3}{c|}{ Material } \\
\cline { 2 - 4 } & Limestone & Sandstone & Granite \\
\hline Young's modulus $E[\mathrm{GPa}]$ & 23.13 & 16.96 & 9.73 \\
\hline Cohesion $c[\mathrm{MPa}]$ & 20 & 31.82 & 18.91 \\
\hline Internal friction angle $\rho\left[^{\circ}\right]$ & 56 & 34 & 44 \\
\hline Uniaxial tensile strength $S_{r}[\mathrm{MPa}]$ & 8.03 & 11.05 & 8.74 \\
\hline Uniaxial compressive strength $S_{c}[\mathrm{MPa}]$ & 158.45 & 122.78 & 95.09 \\
\hline
\end{tabular}

(a)

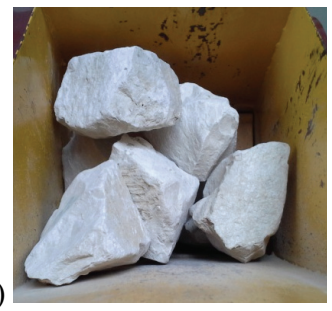

(b)

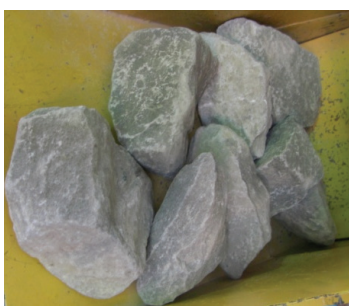

(c)

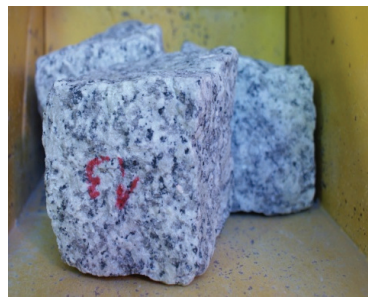

Fig. 2. Examples of feed specimens from mines in Poland with average dimension of $90 \mathrm{~mm}$ used in the tests: (a) limestone "Morawica", (b) sandstone "Mucharz", (c) granite "Strzegom" 
fering from them almost exclusively by dimensions. It is characterized by the following technical parameters: the dimension of the inlet slot $a \times b=100 \times 200 \mathrm{~mm}$, height of the crusher's working chamber $h=250 \mathrm{~mm}$, the outlet slot $e_{r}=20 \div 30 \mathrm{~mm}$, the angular velocity of the drive shaft (no-load running) $n=388 \mathrm{rpm}$, moving jaw displacement $s \approx 6 \mathrm{~mm}$, gear ratio of $\mathrm{V}$ belt 3.2, rated engine power (type SZJe 34b) $N_{z n}=4 \mathrm{~kW}$.

The material used in the tests (feed) was a limestone "Morawica", sandstone "Mucharz" and granite "Strzegom" from mines in Poland (Fig. 2) with strength parameters given in Table 1.

Figure 3 shows research testing scheme. The first crushing process (Fig. 3a) was implemented in two crushing stages, with outlet slot dimension $e_{r}=24 \mathrm{~mm}$ (B) in the first stage and $e_{r}=11 \mathrm{~mm}$ in the second crushing stage $(\mathrm{C}, \mathrm{B})$. After the first stage of crushing, the material was sieved in order to perform our analysis of the product grain. To complete sieve analysis a set of control sieves was used. A set consisting of 10 screens of mesh square size 0.063 , $0.125,0.25,0.5,1,2,4,8,16,31.5 \mathrm{~mm}$ was placed on a mechanical shaker WSU-BB according to Polish Standard (PN-EN 933-1: 2012). Feed used in the second stage had grain sizes of $8,16,31.5 \mathrm{~mm}(\mathrm{C})$ and $16,31.5 \mathrm{~mm}$ (D). The final stage of the research was sieve analysis of the product. The second crushing process proceeded in a single step (A), shown schematically in Fig. 3b. For this process, the outlet slot was set to $e_{r}=11 \mathrm{~mm}$. The feed used in both processes had a similar mass $(\sim 10 \mathrm{~kg})$ and particle size $d=90 \mathrm{~mm}$.

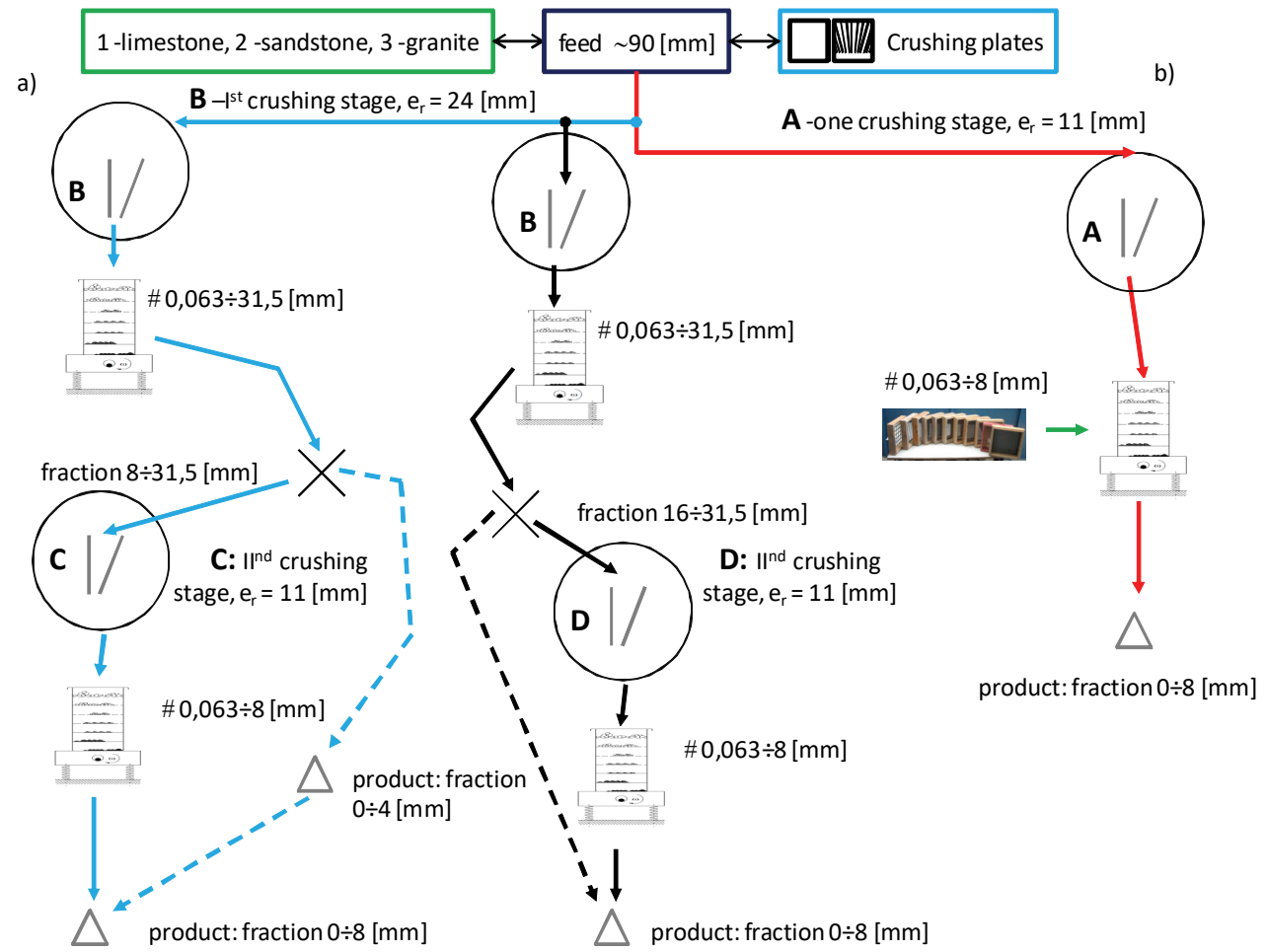

Fig. 3. Research testing scheme: (a) two-stage, (b) one-stage

(a)

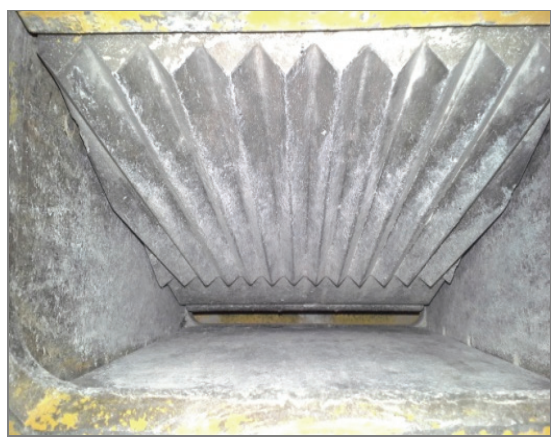

(b)

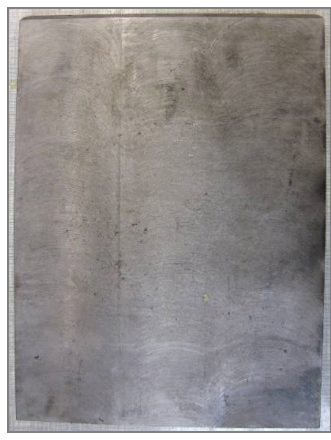

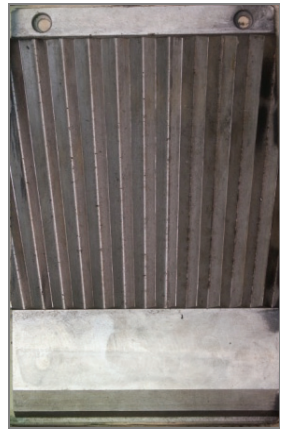

Fig. 4. Crushing plates used in the tests:

(a) crusher's working space - view from the top on crushing plates, (b) a set of flat and profiled plates 
Figure 4 a shows a view of crusher's working space. In this work flat crushing plate for fixed jaw and moving plate with variable pitch and triangular profile were used. This set is advantageous for reasons of performance and energy consumption of the machine crushing process (Ciężkowski and Maciejewski [4]). During the experiments, moving jaw displacement and crushing forces were recorded by measurement of forces on toggle plate 3a, shown in Fig. 1.

\section{RESULTS}

Product particle size distribution is one of the most important indicator of the process. The percentage of each product fraction is defined as

$$
f_{n}=\frac{m_{n}}{m}
$$

where $m$ - specimen mass, $m_{n}-$ mass of fraction " $n$ ".
The results of product sieve analysis are given in Tables 2-4 and Figs. 5-7. Tests were performed on four series. Results of product particle size distribution are averaged from all tests. The tables show values of masses each fraction for one-stage process A, B with the dimension of the outlet slot of consists of $e_{r}=$ $11 \mathrm{~mm}$ and $e_{r}=24 \mathrm{~mm}$ and for second stage of crushing process $\mathrm{C}$ and $\mathrm{D}$ for feed size $d=8 \div 31.5 \mathrm{~mm}$ and $d=16 \div 31.5$. Columns labeled as $\Sigma^{1}$ and $\Sigma^{2}$ contain a summary results of each two-stage crushing process $\mathrm{B}+\mathrm{C}$ and $\mathrm{B}+\mathrm{D}$. The final results of the one- and two-stage sandstone, limestone and granite crushing processes are compared in Figs. 5-7. Product particle size distribution analysis shows that the one-stage process has a similar composition as two-stage process $\mathrm{B}+\mathrm{C}$, where in the second stage the feed size $d=8 \div 31.5 \mathrm{~mm}$ was used. In the case of $\mathrm{B}+\mathrm{D}$ process (feed $d=16 \div 31.5 \mathrm{~mm}$ ) there are many more fractions of $d=8 \mathrm{~mm}$ in relation to one-stage process A or two-stage $\mathrm{B}+\mathrm{C}$.

In order to compare the effects of one- and twostage processes, a group of indicators was introduced.

Table 2. Results of sieve analysis for "Mucharz" sandstone, $\Sigma^{1}=\mathrm{B}+\mathrm{C}, \Sigma^{2}=\mathrm{B}+\mathrm{D}$

\begin{tabular}{|c|c|c|c|c|c|c|}
\hline Dimension of the sieve & \multicolumn{6}{|c|}{ Mass of the rock left on the sieve [g] } \\
\cline { 2 - 7 }- substitute diameter [mm] & A & B & C & $\Sigma^{1}$ & D & $\Sigma^{2}$ \\
\hline$<0.063$ & 0.11 & 0.04 & 0.14 & 0.18 & 0 & 0.04 \\
\hline 0.063 & 0.65 & 0.12 & 0.48 & 0.6 & 0.08 & 0.2 \\
\hline 0.125 & 0.93 & 0.14 & 0.57 & 0.71 & 0.28 & 0.42 \\
\hline 0.25 & 0.57 & 0.11 & 0.44 & 0.55 & 0.38 & 0.49 \\
\hline 0.5 & 0.79 & 0.19 & 0.78 & 0.97 & 1.13 & 1.32 \\
\hline 1 & 1.26 & 0.4 & 0.51 & 0.91 & 1.15 & 1.55 \\
\hline 2 & 1.39 & 0.48 & 1.18 & 1.66 & 1.18 & 1.66 \\
\hline 4 & 3.78 & 0.92 & 2.78 & 3.7 & 1.54 & 2.46 \\
\hline 8 & 0.79 & 1.66 & 0.74 & 0.74 & 0.22 & 1.88 \\
\hline 16 & 0 & 5.58 & 0 & 0 & 0 & 0 \\
\hline 31.5 & 0 & 0.38 & 0 & 0 & 0 & 0 \\
\hline$m=\sum m_{i}$ & $\mathbf{1 0 . 2 7}$ & $\mathbf{1 0 . 0 2}$ & $\mathbf{7 . 6 2}$ & $\mathbf{1 0 . 0 2}$ & $\mathbf{5 . 9 6}$ & $\mathbf{1 0 . 0 2}$ \\
\hline
\end{tabular}

Table 3. Results of sieve analysis for "Morawica" limestone

\begin{tabular}{|c|c|c|c|c|c|c|}
\hline Dimension of the sieve & \multicolumn{7}{|c|}{ Mass of the rock left on the sieve [g] } \\
\cline { 2 - 7 } - substitute diameter [mm] & $\mathrm{A}$ & $\mathrm{B}$ & $\mathrm{C}$ & $\Sigma^{1}$ & $\mathrm{D}$ & $\Sigma^{2}$ \\
\hline$<0.063$ & 0.02 & 0.01 & 0.02 & 0.03 & 0.02 & 0.03 \\
\hline 0.063 & 0.1 & 0.04 & 0.3 & 0.34 & 0.04 & 0.08 \\
\hline 0.125 & 0.42 & 0.09 & 0.72 & 0.81 & 0.12 & 0.21 \\
\hline 0.25 & 0.45 & 0.1 & 0.65 & 0.75 & 0.29 & 0.39 \\
\hline 0.5 & 1.2 & 0.2 & 1.19 & 1.39 & 0.56 & 0.76 \\
\hline 1 & 2.3 & 0.3 & 1.35 & 1.65 & 1.15 & 1.45 \\
\hline 2 & 1.82 & 0.41 & 1.23 & 1.64 & 1.31 & 1.72 \\
\hline 4 & 3.52 & 1.08 & 1.97 & 3.05 & 1.45 & 2.53 \\
\hline 8 & 0.49 & 2.42 & 0.27 & 0.27 & 0.37 & 2.79 \\
\hline 16 & 0 & 4.29 & 0 & 0 & 0 & 0 \\
\hline 31.5 & 0 & 1.02 & 0 & 0 & 0 & 0 \\
\hline$m=\sum m_{i}$ & $\mathbf{1 0 . 3 2}$ & $\mathbf{9 . 9 6}$ & $\mathbf{7 . 7}$ & $\mathbf{9 . 9 6}$ & $\mathbf{5 . 3 1}$ & $\mathbf{9 . 9 6}$ \\
\hline
\end{tabular}


Table 4. Results of sieve analysis for "Strzegom" granite

\begin{tabular}{|c|c|c|c|c|c|c|}
\hline Dimension of the sieve & \multicolumn{7}{|c|}{ Mass of the rock left on the sieve $[\mathrm{g}]$} \\
\cline { 2 - 7 } - substitute diameter [mm] & $\mathrm{A}$ & $\mathrm{B}$ & $\mathrm{C}$ & $\Sigma^{1}$ & $\mathrm{D}$ & $\Sigma^{2}$ \\
\hline$<0.063$ & 0.11 & 0.02 & 0.15 & 0.17 & 0.10 & 0.12 \\
\hline 0.063 & 0.24 & 0.1 & 0.29 & 0.39 & 0.13 & 0.23 \\
\hline 0.125 & 0.43 & 0.16 & 0.48 & 0.64 & 0.23 & 0.39 \\
\hline 0.25 & 0.48 & 0.19 & 0.52 & 0.71 & 0.29 & 0.48 \\
\hline 0.5 & 1.07 & 0.36 & 1.2 & 1.56 & 0.59 & 0.95 \\
\hline 1 & 1.56 & 0.4 & 1.18 & 1.58 & 0.68 & 1.08 \\
\hline 2 & 1.75 & 0.48 & 1.17 & 1.65 & 0.75 & 1.23 \\
\hline 4 & 3.46 & 0.85 & 2.04 & 2.89 & 1.37 & 2.22 \\
\hline 8 & 0.89 & 1.48 & 0.23 & 0.23 & 1.63 & 3.11 \\
\hline 16 & 0 & 4.91 & 0 & 0 & 0.00 & 0 \\
\hline 31.5 & 0 & 0.86 & 0 & 0 & 0.00 & 0 \\
\hline$m=\sum m_{i}$ & $\mathbf{9 . 9 9}$ & $\mathbf{9 . 8 1}$ & $\mathbf{7 . 2 5}$ & $\mathbf{9 . 8 1}$ & $\mathbf{5 . 7 7}$ & $\mathbf{9 . 8 1}$ \\
\hline
\end{tabular}

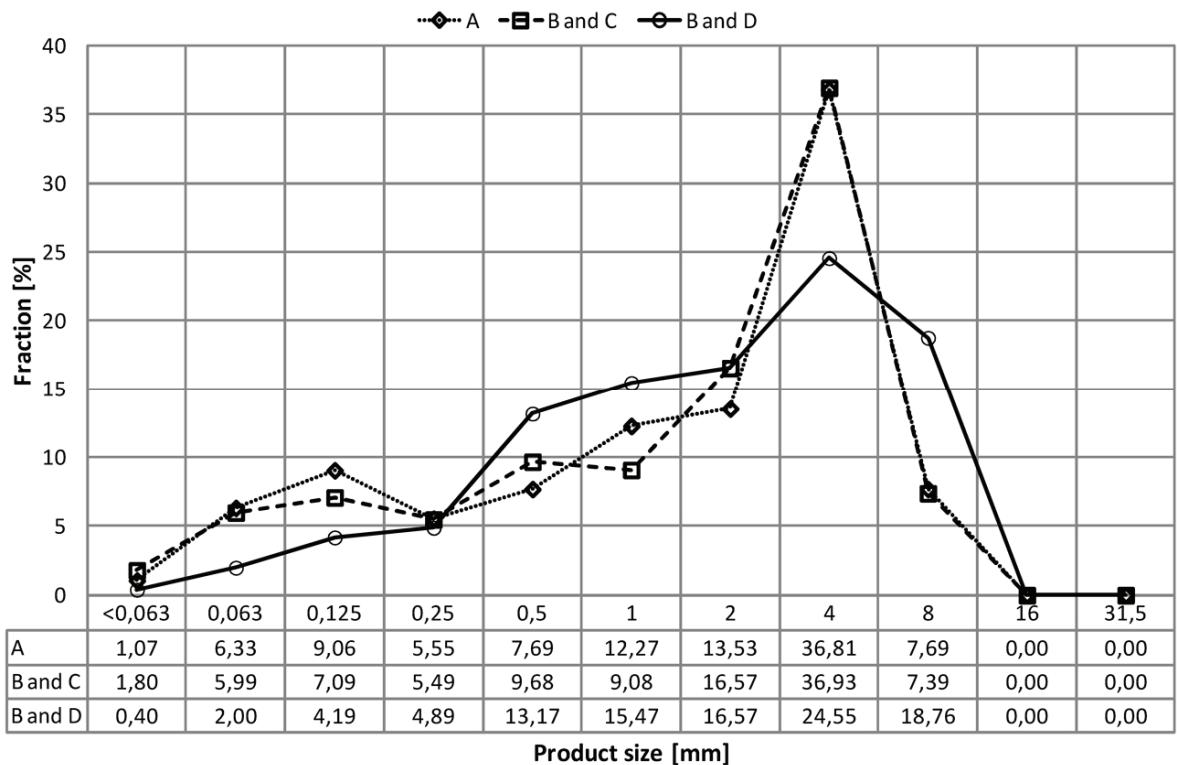

Fig. 5. Sieve analysis. Comparison of one-stage and two-stage sandstone crushing process

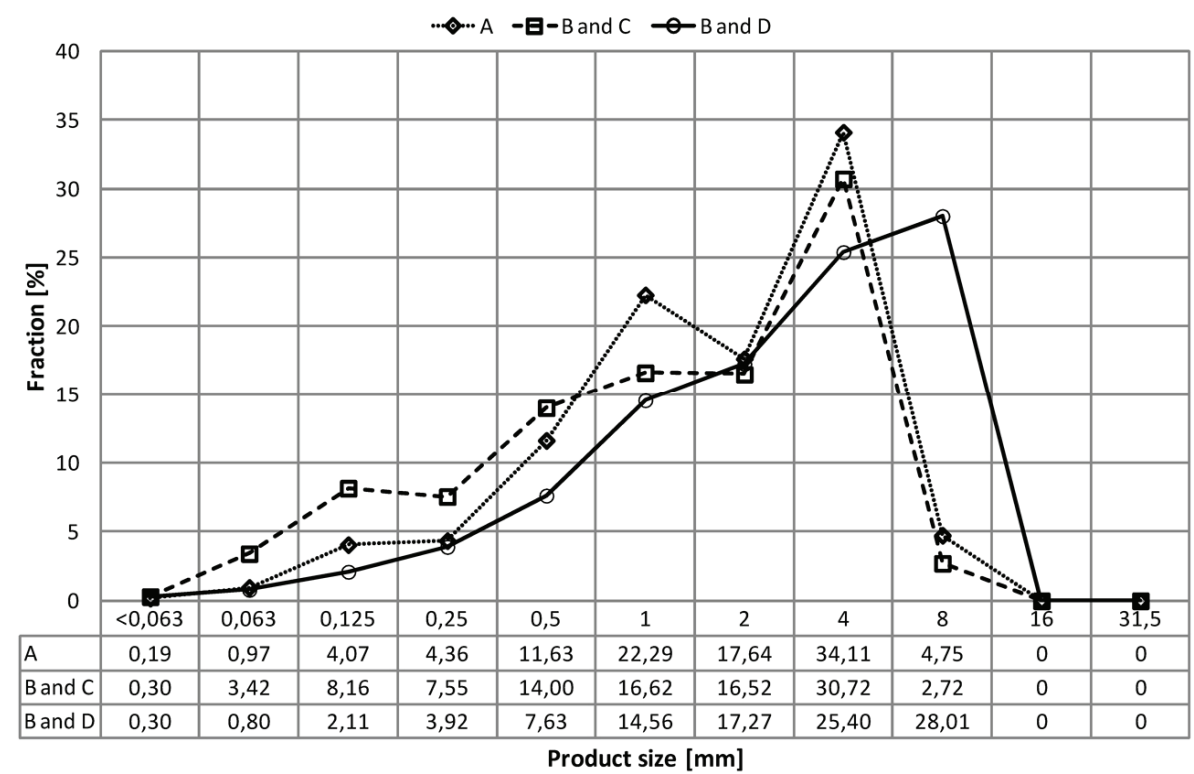

Fig. 6. Sieve analysis. Comparison of one-stage and two-stage limestone crushing process 


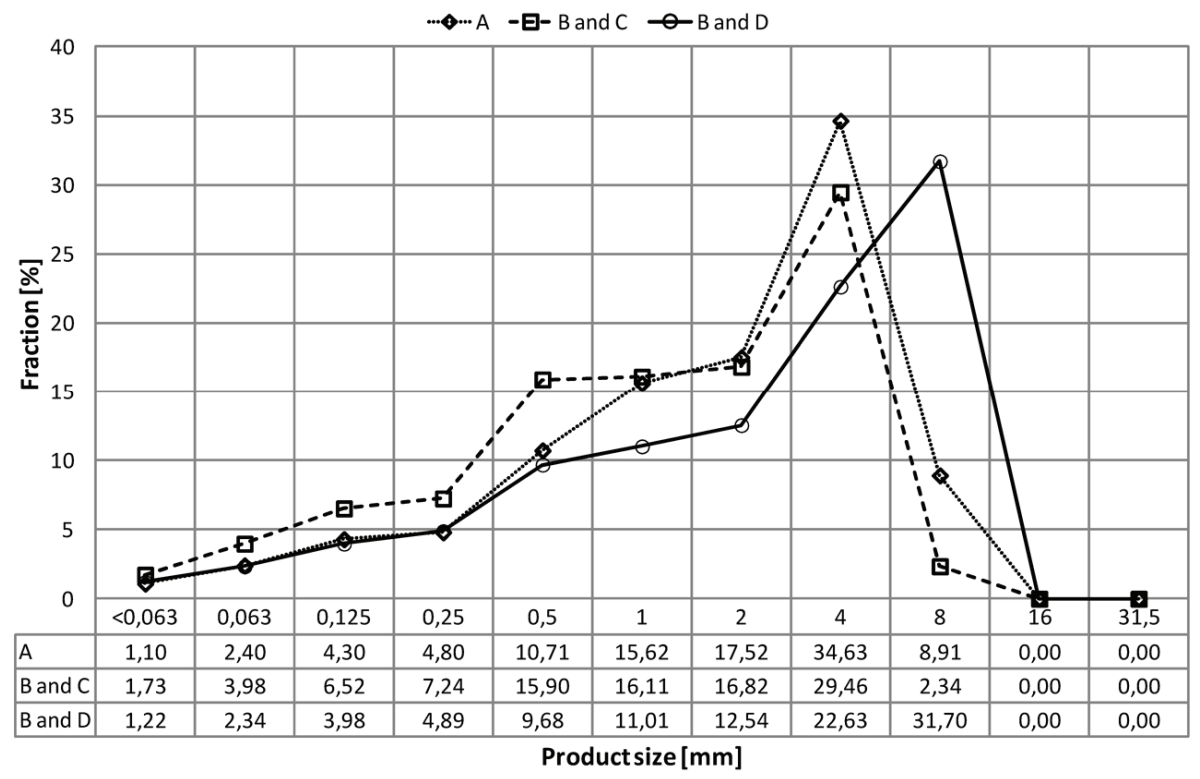

Fig. 7. Sieve analysis. Comparison of one-stage and two-stage granite crushing processes

These indicators are pertaining to forces, energy and performance, namely:

- $F_{\max }$ - average value of the maximum crushing forces given by

$$
F_{\max }=\frac{1}{k} \sum_{i=1}^{k} F_{i \max }
$$

where: $F_{i \max }$ are maximum values in subsequent cycles of operation, $k$-number of subsequent cycles of operation. This definition means the average of the maximum values recorded for each portion of feed,

- $W_{t}$ - technical performance - feed mass to crushing time ratio $W_{t}=m / t$,

- effective energy $L_{e}$ - is equal to the amount of work generated in subsequent crushing cycles. Effective energy of one cycle is equal to the area shown in Fig. 8.

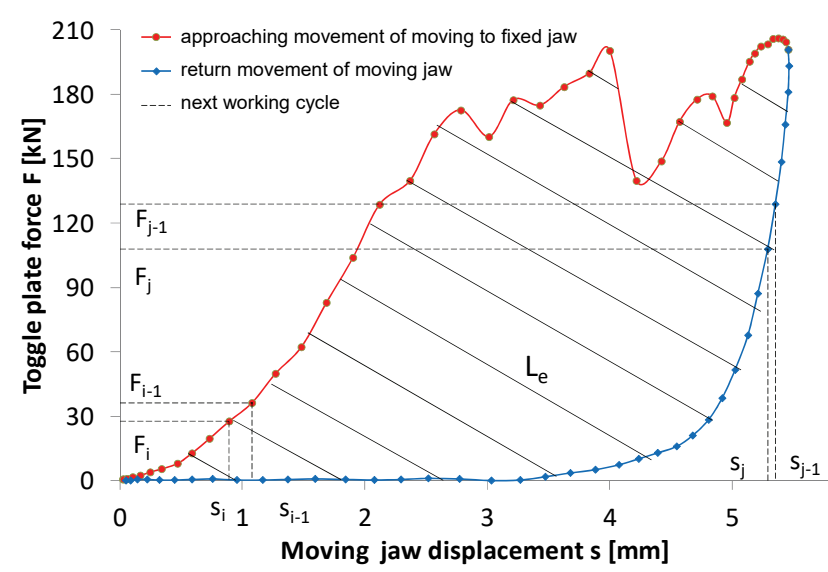

Fig. 8. Selected work cycle of sandstone crushing by flat plates. Force vs. displacement diagram

$$
L_{e}=\sum_{i=1}^{k} \frac{F_{i+1}+F_{i}}{2}\left(s_{i+1}-s_{i}\right)
$$

- specific crushing energy - the crushing energy related to feed mass

$$
L_{s}=\frac{L_{e}}{m}
$$

In Table 5, results obtained for analyzed processes of three types of rock crushing are presented. There are shown values of average forces $F_{\max }$, effective and specific energy, technical performance for one-stage process $\mathrm{A}$ and two-stage processes $\mathrm{B}+\mathrm{C}$ and $\mathrm{B}+\mathrm{D}$.

Comparing the force values it can be seen that the crushing forces are strongly related to outlet slot dimension. In the case of crushing sandstone and granite, the force is three times less for $e_{r}=24 \mathrm{~mm}$ (process B) than for process A, where $e_{r}=11 \mathrm{~mm}$. For limestone crushing, the force is 7 times less for $e_{r}=$ $24 \mathrm{~mm}$ (processes C and D).

In the second stage with outlet slot $e_{\mathrm{r}}=11 \mathrm{~mm}$ values of forces are similar to results obtained for onestage process A despite the significant difference of feed size (A $\sim d=90 \mathrm{~mm}, \mathrm{C}-d=8 \div 31.5 \mathrm{~mm}$, $\mathrm{D}=16 \div 31.5 \mathrm{~mm}$ ). Comparing the effective energy of both processes, we see that the two-stage process is advantageous compared to the single one. Two-stage process $\mathrm{B}+\mathrm{C}$, where in the second stage a fraction of $8 \div 31.5 \mathrm{~mm}$ was crushed, gives $8.8 \%$ lower energy consumption for sandstone and $40 \%$ for granite but $5 \%$ higher for limestone.

In the case of two stage process B + D the advantage in terms of energy is much larger, and is 
Table 5. Crushing force, crushing energy and technical performance - experiment

\begin{tabular}{|l|c|c|c|c|c|c|c|}
\hline \multirow{2}{*}{ Process } & One-stage & \multicolumn{5}{|c|}{ Two-stage } \\
\cline { 2 - 8 } & A & B & C & B and C & D & B and D \\
\hline Material & \multicolumn{7}{|c|}{ Sandstone "Mucharz" } \\
\hline Feed $[\mathrm{mm}]$ & 90 & 90 & $8,16,31,5$ & $\Sigma$ & $16,31,5$ & $\Sigma$ \\
\hline Outlet slot $e_{r}[\mathrm{~mm}]$ & 11 & 24 & 11 & 24 and 11 & 11 & 24 and 11 \\
\hline Effective energy $L_{e}[\mathrm{~kJ}]$ & $\mathbf{1 0 4 . 6 2}$ & 28.41 & 67.75 & $\mathbf{9 6 . 1 6}$ & 52.81 & $\mathbf{8 1 . 2 2}$ \\
\hline Specific energy $L_{s}[\mathrm{~kJ} / \mathrm{kg}]$ & $\mathbf{1 0 . 1 9}$ & - & - & $\mathbf{9 . 6 0}$ & - & $\mathbf{8 . 1 1}$ \\
\hline Average forces $F_{\max }[\mathrm{kN}]$ & 346.09 & 112.87 & 359.68 & - & 329.14 & - \\
\hline Technical performance $W_{t}[\mathrm{~kg} / \mathrm{s}]$ & 0.14 & 0.56 & 0.15 & 0.15 & 0.15 & 0.19 \\
\hline Crushing time $t[\mathrm{~s}]$ & 69.49 & 17.86 & 49.85 & 67.71 & 35.43 & 53.29 \\
\hline Material & \multicolumn{7}{|c|}{ Limestone “Morawica “ } \\
\hline Effective energy $L_{e}[\mathrm{~kJ}]$ & $\mathbf{9 4 . 5 5}$ & 19.24 & 80.31 & $\mathbf{9 9 . 5 5}$ & 49.79 & $\mathbf{6 9 . 0 3}$ \\
\hline Specific energy $L_{s}[\mathrm{~kJ} / \mathrm{kg}]$ & $\mathbf{9 . 1 6}$ & - & - & $\mathbf{9 . 9 9}$ & - & $\mathbf{6 . 9 3}$ \\
\hline Average forces $F_{\max }[\mathrm{kN}]$ & 354.82 & 51.49 & 377.83 & - & 284.59 & - \\
\hline Technical performance $W_{t}[\mathrm{~kg} / \mathrm{s}]$ & 0.11 & 0.41 & 0.15 & 0.13 & 0.14 & 0.15 \\
\hline Crushing time $t[\mathrm{~s}]$ & 72.11 & 21.2 & 50.2 & 71.4 & 36.21 & 57.41 \\
\hline \multicolumn{7}{|c|}{ Material } & \multicolumn{7}{|c|}{ Granite “Strzegom" } \\
\hline Effective energy $L_{e}[\mathrm{~kJ}]$ & $\mathbf{9 0 . 8 6}$ & 16.88 & 36.51 & $\mathbf{5 3 . 3 9}$ & 32.31 & $\mathbf{4 9 . 1 9}$ \\
\hline Specific energy $L_{s}[\mathrm{~kJ} / \mathrm{kg}]$ & $\mathbf{9 . 1 0}$ & - & - & $\mathbf{5 . 4 4}$ & - & $\mathbf{5 . 0 1}$ \\
\hline Average forces $F_{\max }[\mathrm{kN}]$ & 190.92 & 67.02 & 244.40 & - & 184.28 & - \\
\hline Technical performance $W_{t}[\mathrm{~kg} / \mathrm{s}]$ & 0.16 & 0.45 & 0.30 & 0.22 & 0.31 & 0.22 \\
\hline Crushing time $t[\mathrm{~s}]$ & 56 & 21.50 & 24.34 & 45.84 & 23.44 & 44.94 \\
\hline
\end{tabular}

equal to $22 \%$ for sandstone, $26 \%$ for limestone and $45 \%$ for granite.

A comparison of technical performance shows that the two-stage process is preferred. The technical performance of the process $(\mathrm{B}+\mathrm{D})$ is $30 \%$ higher relative to the one-step process $A$.

\section{CONCLUSIONS}

In the paper, the experimental comparison of two machine crushing technologies - one-stage and twostage was presented. The laboratory tests were carried out on a model double-toggle jaw crusher on the three rocks: granite "Strzegom", limestone "Morawica" and sandstone "Mucharz".

Analyzing the result, the following conclusions can be drawn:

- Product particle size distribution analysis shows that the one-stage process $\mathrm{A}$ has a similar composition to two-stage process $\mathrm{B}+\mathrm{C}$, where in the second stage the feed size $d=8 \div 31.5 \mathrm{~mm}$ was used. In the case of two-stage process $\mathrm{B}+\mathrm{D}$ (feed size $d=16 \div 31.5 \mathrm{~mm}$ ) there are many more fractions of $d=8 \mathrm{~mm}$ in relation to one-stage process A or two-stage B + C.

- The average crushing forces values Fmax are strongly related to outlet slot dimension. In the case of crushing sandstone and granite, the force is three times less for $e_{r}=24 \mathrm{~mm}$ (process B) than for process A, where $e_{r}=11 \mathrm{~mm}$. For limestone crushing, the force is 7 times less for $e_{r}=24 \mathrm{~mm}$ (processes $\mathrm{C}$ and $\mathrm{D}$ ).

- Comparing the effective energy of both processes, we see that the two-stage process is advantageous compared to the single one. In the analysed processes energy consumption was lower from 8 to $45 \%$ in the case of two-stage processes.

- The technical performance of the two-stage process $(B+D)$ is $30 \%$ higher relative to the one-step process A or two-stage process $\mathrm{B}+\mathrm{C}$.

The results were obtained using the laboratory jaw crusher, with a special design of the jaw with variable profile and pitch. In earlier studies (Ciężkowski et al. [5]) it was demonstrated that this type of jaws is preferred due to the force value and energy consumption.

Since the results obtained in this research are propmising, its continuation is fully justified.

\section{REFERENCES}

[1] Akbarnezhad A., Ong K.C.G., TAm C.T., Zhang M.H., Effects of the parent concrete properties and crushing procedure on the properties of coarse recycled concrete aggregates, Journal of Materials in Civil Engineering, 2013, (12) $25,1795-1802$. 
[2] CiĘżKowski P., Correlation of energy consumption and shape of crushing plates, Górnictwo i Geoinżynieria, 2012, 91-100.

[3] CiĘżKowski P., Doświadczalne badania sit kruszenia szczękami o różnym ksztalcie, Zeszyty Naukowe Instytutu Pojazdów, 2012, 2, 88, 21-34.

[4] CiĘżKowski P., Maciejewski J., Badania $i$ analiza maszynowego procesu rozdrabniania wapienia zwartego Morawica, Przegląd Mechaniczny, 2014, nr 5, 35-41, ISSN: 0032-2259.

[5] CiężKowski P., Maciejewski J., BĄK S., KuŚMierczyK J., Study on the Efficiency of the Crushing Processes Using the Model of Jaw Crusher, Machine Dynamics Research, 2015, Vol. 39, No 2, 123-132.

[6] CiĘżKowski P. (ed.), Kruszenie skat - teoria, eksperyment $i$ zastosowania inżynierskie, (P. Ciężkowski), Instytut Technologii Eksploatacji - PIB, Radom ul. K. Pułaskiego 6/10, Radom, 26-600: Instytut Maszyn Roboczych Ciężkich, 2016.

[7] Foszcz D., GAWENDA T., Analiza efektywności procesu mielenia $w$ mlynach kulowych i prętowych $w$ zależności od zawartości ziaren drobnych, Journal of Mining and Geoengineering, 2012, Vol. 36, No. 4, 17-30.

[8] GAWENDA T., Rozdrabnianie surowców skalnych w kruszarce szczękowej typu L44.41, Surowce i Maszyny Budowlane, 2010, nr 2, 37-42, Wydawnictwo BMP, Racibórz 10.

[9] Foszcz D., WŁodARCZYK W., Wplyw warunków rozdrabniania dolomitów $w$ kruszarkach szczękowych na skład ziarnowy produktów, Gospodarka Surowcami Mineralnymi, 1999, Vol. 15, Special Issue, 317-325.
[10] Fuerstenau D.W., AbouZeid A.-Z.M., Role of feed moisture in high-pressure roll mill comminution, International Journal of Mineral Processing, 2007, Vol. 82.

[11] Klushancev B.V., LogaK L., Bogucki A.J., Wliyanie konstrukcii drobyashchikh plit na effektivnost raboty, Stroit. i Dorozhn. Mash., 1971, 8.

[12] KobialKa R., Naziemiec Z., Badania procesu kruszenia szczękami o rożnym profilu poprzecznym, Górnictwo i Geoinżynieria, 2006, nr 30, zeszyt 3/1, 125-136.

[13] Standard PN-EN 933-1: 2012, Badania geometrycznych właściwości kruszyw, Część 1: Oznaczanie składu ziarnowego, Metoda przesiewania.

[14] RumpF H., Struktur der Zerkleinerungswissenschaft, Aufbereitungs-Technik, 1966, 8, 421-435.

[15] TęSIOROWSKi J., Teoretyczne podstawy określania krytycznej ilości cykli roboczych kruszarek szczękowych, Polit. Śl. Symp. Nauk. Podstawowe Problemy Procesów Rozdrabniania, Gliwice 1981.

[16] Tromans D., Mineral Comminution: Energy Efficiency Considerations, Minerals Engineering, 2008, 21, 613-620.

[17] ZAWADA J., PAWLAK W.R., Einfluß der Oberflachenform von brechplatten für backenbrecher auf das Zerkleinerungsergebnis, Aufbereitungs-Technik, 1988, Nr. 3.

[18] Mierzwa P., OlejNIK E., JANAS A., Nowoczesne materiaty kompozytowe zastepujace tradycyjne materiały odlewnicze, Archives of Foundry Engineering, 2012, Vol. 12, Special Issue 1, 137-142, ISSN 1897-3310.

[19] Numbia B.P., Zhanga J., XIAA X., Optimal energy management for a jaw crushing process in deep mines, Energy, 15 April 2014, Vol. 68, 337-348, http://doi.org/10.1016/ j.energy.2014.02.100. 